(RESEARCH ARTICLE)

\title{
Microbial contamination correlated to hygienic habits attitudes and practices toward handling contact lens units
}

\author{
Zahira Murhaf AL-Khani and Hadeel T. AL-Hadithi * \\ Faculty of Pharmacy / Isra University / Jordan.
}

Publication history: Received on 21 September 2020; revised on 22 November 2020; accepted on 25 November 2020

Article DOI: https://doi.org/10.30574/wjarr.2020.8.2.0352

\begin{abstract}
Introduction: Contact lenses (CLs) are medical or cosmetic devices, comfortable and more convenient alternative to eyeglasses. Eye infection will result when microbes are introduced onto CLs, because defense against microbial invasion in the anterior chamber of the eyes is weak due to the very poor blood supply.

Method: The present study investigates hygienic habits, attitudes and practices of thirty CL wearers, toward lens care, that might yield to microbial contamination of CL units through examination of 120 samples (4 items of each CL units) to detect microbial growth and to understand associated factors through a structured questionnaire.

Results: Microbial contamination was detected in at least one item of twenty-five CL units (83.3\%). None of disinfecting care solutions in original bottles was found contaminated. Incidence of microbial contamination in storage case (Right and Left) and rims of solution bottles was 21 (70\%), 17 (56.7\%) and 6 (20\%) respectively. Eye redness after CLs wearing was almost a statistically significant sign associated with contaminated CL units $(\mathrm{p}=0.088)$. Using water only to wash hands and CL storage cases has been incriminated for increased contamination.

Conclusions: Impurities in CL storage cases have led to reduced efficacy of disinfectant care solutions. Value-added awareness of CL wearers should be improved by regular visit to eye care professionals.
\end{abstract}

Keywords: Contact lens units; Microbial Contamination; Hygienic Habits; Attitudes and Practices.

\section{Introduction}

Contact lenses are thin, light weight, almost invisible disks that serve as an excellent option and alternative to eyeglassesfor people who need vision correction. Currently, ninety percent of contact lens wearers use soft contact lenses [1, 2] which were first introduced to the U.S. in 1971 [3]. Centers for Disease Control and Prevention [4] have estimated that 45 million people in the U.S. wear CLs, two third of them are female with average age of 31 years. It is estimated that CL wearers are in excess of 150 million wearers [5]. The most common complications caused due to long term wearing CLs are minor including: discomfort, dryness and irritancy of eyes, burning when putting in lenses, allergy and physiological problems [6]. Fortunately, most problems are not serious and will resolve if the lens is removed for a period of time [7]. Major problems, although less common, but may be more dangerous for vision include: Conjunctive problems [8] particularly, allergic conjunctivitis [9] and Microbial Keratitis [10,11] which may result in impaired vision [12] and deterioration of quality of life [13]. The eyes may get worse by different factors such as smoking, dust, airconditioned rooms, and medication. Besides, wearing CL while sleeping have led to increased prevalence and severity of all complications especially the risk of Microbial Keratitis [6, 14].

Hygiene of CLs and their storage cases is necessary for safe wear, despite using disinfecting agent, CLs storage cases are the most allegeable item to get contamination [15,16] Commensals (Resident) and transient potential

\footnotetext{
${ }^{*}$ Corresponding author: Hadeel T. AL-Hadithi

Faculty of Pharmacy / Isra University / Jordan.
}

Copyright (C) 2020 Author(s) retain the copyright of this article. This article is published under the terms of the Creative Commons Attribution Liscense 4.0. 
microorganisms (M.O) may approach lenses from wearer's fingers and eyelid edges while inserting lenses from CL storage cases, which in turn will be introduced to the disinfectant care solution resulting in decreased preservative efficacy; thereby, this solution will act as a good substrate for these microbes [17]. Accordingly, CLs acts as a vector to adhere to and transfer to the ocular surface resulting in inflammation or infection $[18,19,20,2122$

Disinfecting care solutions are improved over the years to become more efficient for surface cleaning and sterilization of CLs. it contains combinations of cleaning, disinfecting, moisturizing, and preventing of tear agents [23]. Yet, CL disinfecting care solutions with the same formulations, but manufactured by different companies, may possess different disinfecting potentials [24]. Besides, Dantam et al.[25] indicated that extent of microbial contamination of storage cases varies with the use of different formulations of CL care solutions.

Therefore, the aim of the present study is to investigate microbial contamination correlated to hygienic habits, attitudes and practices toward handling CL units.

\section{Material and methods}

Samples were collected through the period from October 2019 to March 2020. Participants are students currently wearing CLs (either long- lastingor daily use), randomly selected from colleges at Isra University aged $>18$ years. They signed the informed consent without any obligation; inquiries were answered and clarified at request. They were not taking any antibiotic nor eye medications [26] and no one was suffering from any eye disease, inflammation or infection at the time of sampling.

\subsection{Questionnaire}

Questions were constructed after searching through various articles [20,26, 27, 28 ] and the part of questionnaire considering recommendations for CLs wearing was determined according to American Optometric Association [29]. Questionnaire included demographic data, eye-related health, personal hygienic habits, and CLs hygienic habits; some of which are close-ended and others are open-ended. No names were included in the survey and no financial reward was given.

\subsection{Sampling}

One hundred and twenty samples were taken from CL units of 30 participants These included immersion disinfectant care solutions from: (1) Right and (2) Left CL Storage Case (RSC and LSC respectively), (3) disinfectant care solution from its original bottle and (4) swabbing mouth rims of disinfectant solution bottles.

Under sterile conditions, $0.5 \mathrm{ml}$ immersion solutions from each RSC and LSC, from care solution and swabs were suspended in $4.5 \mathrm{ml}$ Trypticase Soy Broth (TSB, biolab) containing 3\% Tween 80 (Polysorbate 80) to neutralize the effect of disinfectant [30-31] then incubated at $35^{\circ} \mathrm{C}$ for $1-2 \mathrm{hrs}$., to allow stressed microbial cells to recover. Two-fold dilutions of each sample $(100 \mu$ Land $50 \mu \mathrm{L})$ were spread onto duplicate Trypticase Soy Agar (TSA, biolab) plates using sterile L-shaped solid glass rod (Dipped into spirit then flamed). Plates were incubated at $35^{\circ} \mathrm{C}$ for $24-48 \mathrm{hrs}$. Growth of 10 or more bacterial colonies on plates was reported as contamination [30].

\subsection{Statistical Analysis}

All statistical analyses were conducted using SPSS software version 25 for Windows. $p$ value of equals or less than 0.05 was set as the significance level. Participant characteristics were reported by using means and standard deviations (SD) for continuous variables while frequencies with percentages were used for categorical variables. A dichotomous variable that represent bacterial isolate status was generated and was used to compare contaminated and noncontaminated samples using Chi square test $(\chi 2)$.

\section{Results}

Microbial contamination was detected in at least one item of twenty-five CL units (83.3\%). None of disinfecting care solutions in original bottles was found contaminated. Incidence of microbial contamination in RSC and LSC and rims of solution bottles was 21 (70\%), 17 (56.7\%) and 6 (20\%) respectively. Only one bottle rim was found contaminated (3.3\%) without its storage case. Demographic characteristics as correlated to microbial contamination are illustrated in Table (1). A total of thirty CL wearers participated in the present study, all of them were females; age ranged between 19 - 36 years $(\overline{\mathrm{x}}=23.5$ years, $\mathrm{SD} \pm 3.2$ years).The majority are undergraduate university students $(86.7 \%)$, attending health-related colleges (63.3\%) and studied a microbiology course (60\%). All post graduate students are also studying 
at health-related colleges. The overwhelming majority of participants are non-smokers (86.7\%). Sixteen participants (53.3\%) use CLs for cosmetic reasons while the remaining use CLs for medical reasons. Wearing CLs daily was associated with the least incidence of microbial contamination (72.7\%) as compared to weekly (100\%) or monthly (85.7\%). Additionally, long-lasting CLs were the most popular type used (86.7\%). Almost all participants (96.7\%) are wearing CLs for at least one year.

Table 1 Demographics data of contact lens wearers

\begin{tabular}{|c|c|c|c|c|}
\hline Demographic Data & Response & $\begin{array}{l}N=30 \\
\text { n (\%) }\end{array}$ & $\begin{array}{c}\text { Microbial } \\
\text { contamination } \\
n=25(\%)\end{array}$ & $P$-value \\
\hline \multirow[t]{2}{*}{ Health education* } & Yes & $19(63.3 \%)$ & $16(84.2 \%)$ & \multirow[t]{2}{*}{0.865} \\
\hline & No & $11(36.7 \%)$ & $9(81.8 \%)$ & \\
\hline \multirow[t]{2}{*}{ Educational level } & Undergraduates & $26(86.7 \%)$ & $22(84.6 \%)$ & \multirow[t]{2}{*}{0.631} \\
\hline & Post graduates & $4(13.3 \%)$ & $3(75.0 \%)$ & \\
\hline \multirow[t]{2}{*}{ Studied microbiology } & Yes & $18(60 \%)$ & $15(83.3 \%)$ & \multirow[t]{2}{*}{1.000} \\
\hline & No & $12(40 \%)$ & $10(83.3 \%)$ & \\
\hline \multirow[t]{2}{*}{ CLs experience } & $\geq$ One year & $29(96.7 \%)$ & $24(82.8 \%)$ & \multirow[t]{2}{*}{0.649} \\
\hline & $<$ Year & $1(3.3 \%)$ & $1(100 \%)$ & \\
\hline \multirow[t]{2}{*}{ Reason for wearing CLs } & Cosmetic & $16(53.3 \%)$ & $13(81.3 \%)$ & \multirow[t]{2}{*}{0.743} \\
\hline & Medical & $14(46.7 \%)$ & $12(85.7 \%)$ & \\
\hline \multirow[t]{2}{*}{ Type of CLs } & Long-lasting & $26(86.7 \%)$ & $21(80.8 \%)$ & \multirow[t]{2}{*}{0.337} \\
\hline & Daily use (Disposable) & $4(13.3 \%)$ & $4(100 \%)$ & \\
\hline \multirow[t]{2}{*}{ Smoking status } & Yes & $4(13.3 \%)$ & $4(100 \%)$ & \multirow[t]{2}{*}{0.337} \\
\hline & No & $26(86.7 \%)$ & $21(80.8 \%)$ & \\
\hline \multirow{3}{*}{$\begin{array}{l}\text { Frequency of } \\
\text { wearing CLs }\end{array}$} & Daily & $11(36.7 \%)$ & $8(72.7 \%)$ & \multirow[t]{3}{*}{0.378} \\
\hline & Weekly & $5(16.7 \%)$ & $5(100 \%)$ & \\
\hline & Monthly & $14(46.6 \%)$ & $12(85.7 \%)$ & \\
\hline \multirow[t]{4}{*}{ Periods of wearing CLs (hours) } & $1-4$ & $6(20 \%)$ & $5(83.3 \%)$ & \multirow[t]{4}{*}{0.071} \\
\hline & $5-8$ & $14(46.7 \%)$ & $11(78.6 \%)$ & \\
\hline & $9-12$ & $9(30 \%)$ & $9(100 \%)$ & \\
\hline & $>12$ & $1(3.3 \%)$ & - & \\
\hline
\end{tabular}

Table (2) demonstrates eye-related health status. Almost two-thirds (63.3\%) of participants denied having any pervious eye-related medical conditions/diseases. Nine out of eleven CL wearers (36.7\%) had a previous eye-related conditions/disease and received medical examination. Diagnoses included: infection $(n=4)$, inflammation ( $n=3)$ and dryness of eyes $(n=2)$ where microbial contamination was detected at least in one item of CL units belonging to 2, 3 and 2 participants respectively. Reported conjunctivitis and keratitis were treated by antibiotics. None of the participants reported active eye infections at the time of the study. Eye redness after wearing CLs is almost significantly associated with microbial contamination of CL units. Also, CL units of wearers, continuously or intermittently suffering from eyelid boils, were found contaminated. 
Table 2 Previous eye-related medical problems

\begin{tabular}{|c|c|c|c|c|}
\hline Eye complications & Response & $\begin{array}{l}N=30 \\
\text { n (\%) }\end{array}$ & $\begin{array}{c}\text { Microbial } \\
\text { contamination } \\
n=25(\%)\end{array}$ & $P$-value \\
\hline \multirow{2}{*}{$\begin{array}{l}\text { Eye medical condition / } \\
\text { disease }\end{array}$} & Yes & $11(36.7 \%)$ & $9(81.8 \%)$ & \multirow[t]{2}{*}{0.865} \\
\hline & No & $19(63.3 \%)$ & $16(84.2)$ & \\
\hline \multirow{3}{*}{$\begin{array}{l}\text { Eye redness after CL } \\
\text { wearing }\end{array}$} & Always/Often & $5(16.6 \%)$ & $5(100 \%)$ & \multirow{3}{*}{0.088} \\
\hline & Sometimes & $18(60 \%)$ & $16(88.9 \%)$ & \\
\hline & Rarely/Never & $7(23.3 \%)$ & $4(57.1 \%)$ & \\
\hline \multirow[t]{3}{*}{ Eyelid boils } & Always/Often & $2(6.7 \%)$ & $2(100 \%)$ & \multirow{3}{*}{0.401} \\
\hline & Sometimes & $5(16.7 \%)$ & $5(100 \%)$ & \\
\hline & Rarely/Never & $23(76.7 \%)$ & $18(78.3 \%)$ & \\
\hline
\end{tabular}

Most CL wearers (60\%) have received instructions of CLs wearing and caring presented by health professionals. Participants were asked to evaluate their knowledge about instructions: eleven (36.7\%) believed that their information regarding lens care is excellent, while 12 (40\%) and 7 (23.3\%) categorized their information as very good and good respectively. Twenty six (86.7\%) are committed most often to instruction. Regardless of the degree of knowledge or commitment to instructions, microbial contamination was detected in at least one item of their CL units.

Table (3) demonstrates that most CL wearers (86.7\%) do not require assistance for wearing CLs. All wearers wash their hands and dry them prior to CLs application, apart from four (13.3\%) who do not dry their hands after washing. Microbial contamination appeared in CL units of wearers, who wash their hands only with water, and water or soap (alternatively). The majority (83\%) avoided washing their faces with tap water while wearing CLs. Only one participant reported bathing/swimming while wearing CLs and another one shared his contact lenses with other person. Contact lens wearers who scarcely avoid touching their nails with CLs have 83.3\% contamination in their CL units.

Contact lens wearers used two types of multipurpose solutions either included with the CLs when purchasing (53.3\%) or use solutions commercially available in pharmacies (46.7\%).Polyhexamethylene biguanide was the disinfecting agent in all solutions supplied with the CLs, though with different concentrations. The disinfecting agents of the trade names of solutions available in pharmacies are as following: solution A (Polyaminopropyl biguanide), solution B (Polyhexamethylene Biguanide) and solution C (Polyquaternium and Myristamidopropyl dimethylamine) which were used by $7(23.3 \%), 6(20 \%)$ and $1(3.3 \%)$ participants respectively. Microbial contamination detected in CL units associated with solutions included with the CLs when purchasing was $13(81.3 \%)$ and with types A, B and C were 6 (85.7\%), $5(83.3 \%)$ and $1(100 \%)$ respectively.

Hygienic habits toward contact lenses and solutions are shown in Table (4). Few numbers of participants (10.0\%) use a special plastic forceps to apply CLs. More than one half (56.7\%) rinse their CLs with care solution, and only one third rub CLs while rinsing them. Rubbing lens with CL solution is significantly associated with microbial contamination of CL units. Eight participants (27.6\%) reported using tap water instead of the recommended solution to store contact lenses at some points. Percentage of participants using water or using water and CL solution alternatively for washing CL storage cases was (38.9\%) and (16.7\%), respectively. 
Table 3 Personal habits during wearing contact lenses

\begin{tabular}{|c|c|c|c|c|}
\hline Personal habits & Response & $\begin{array}{l}\mathrm{N}=30 \\
\mathrm{n}(\%)\end{array}$ & $\begin{array}{c}\text { Microbial } \\
\text { Contamination } \\
n=25(\%)\end{array}$ & $P$-value \\
\hline \multirow[t]{2}{*}{ Personal use of CLs } & Yes & $29(96.7 \%)$ & $24(82.8 \%)$ & \multirow[t]{2}{*}{0.649} \\
\hline & No & $1(3.3 \%)$ & $1(100 \%)$ & \\
\hline \multirow{3}{*}{$\begin{array}{l}\text { Assistance required to wear } \\
\text { CLs }\end{array}$} & Always/ Often & $2(6.7 \%)$ & $1(20 \%)$ & \multirow{3}{*}{0.362} \\
\hline & Sometimes & $2(6.7 \%)$ & $2(100 \%)$ & \\
\hline & Rarely/ Never & $26(86.7 \%)$ & $22(84.6 \%)$ & \\
\hline \multirow[t]{3}{*}{ Hand washing before wearing } & Always/ Often & $30(100.0 \%)$ & $25(83.3 \%)$ & \multirow{3}{*}{ - } \\
\hline & Sometimes & - & - & \\
\hline & Rarely/ Never & - & - & \\
\hline \multirow[t]{3}{*}{ Hand washing by: } & Soap & $22(73.3 \%)$ & $17(77.3 \%)$ & \multirow{3}{*}{0.336} \\
\hline & Water & $4(13.3 \%)$ & $4(100 \%)$ & \\
\hline & $\begin{array}{l}\text { Soap or water } \\
\text { (alternative) }\end{array}$ & $4(13.3 \%)$ & $4(100 \%)$ & \\
\hline \multirow[t]{3}{*}{ Drying washed hand } & Always/ Often & $26(86.7 \%)$ & $21(80.8 \%)$ & \multirow{3}{*}{0.337} \\
\hline & Sometimes & $4(13.3 \%)$ & $4(100 \%)$ & \\
\hline & Rarely/ Never & - & - & \\
\hline \multirow{3}{*}{$\begin{array}{l}\text { Avoiding touching CLs with } \\
\text { fingernails }\end{array}$} & Always/ Often & $8(26.7 \%)$ & $7(87.5 \%)$ & \multirow{3}{*}{0.861} \\
\hline & Sometimes & $4(13.3 \%)$ & $3(75 \%)$ & \\
\hline & Rarely/ Never & $18(60.0 \%)$ & $15(83.3 \%)$ & \\
\hline \multirow[t]{3}{*}{ Sleeping while wearing CLs } & Always/ Often & - & - & \multirow{3}{*}{-} \\
\hline & Sometimes & - & - & \\
\hline & Rarely/ Never & $30(100.0 \%)$ & $25(83.3 \%)$ & \\
\hline \multirow{3}{*}{$\begin{array}{l}\text { Bathing or swimming while } \\
\text { wearing CLs }\end{array}$} & Always/ Often & $1(3.3 \%)$ & - & \multirow{3}{*}{0.023} \\
\hline & Sometimes & - & - & \\
\hline & Rarely/ Never & $29(96.7 \%)$ & $25(86.2)$ & \\
\hline \multirow{3}{*}{$\begin{array}{l}\text { Washing face while wearing } \\
\text { CLs }\end{array}$} & Always/ Often & $1(3.3 \%)$ & - & \multirow{3}{*}{0.061} \\
\hline & Sometimes & $4(13.3 \%)$ & $3(75 \%)$ & \\
\hline & Rarely/ Never & $25(83.3 \%)$ & $22(88 \%)$ & \\
\hline \multirow{3}{*}{$\begin{array}{l}\text { Avoiding smoking places while } \\
\text { wearing CLs }\end{array}$} & Always/ Often & $12(40.0 \%)$ & $10(83.3 \%)$ & \multirow{3}{*}{0.698} \\
\hline & Sometimes & $8(26.7 \%)$ & $6(75 \%)$ & \\
\hline & Rarely/ Never & $10(33.3 \%)$ & $9(90 \%)$ & \\
\hline
\end{tabular}


Table 4 Hygienic habits toward contact lenses and solutions

\begin{tabular}{|c|c|c|c|c|}
\hline Hygienic Habits & Responses & $\begin{array}{l}\mathrm{N}=30(\%) \\
\mathrm{n}(\%)\end{array}$ & $\begin{array}{c}\text { Microbial } \\
\text { Contamination } \\
\mathbf{n}=25(\%)\end{array}$ & $\begin{array}{c}P \text { - } \\
\text { value }\end{array}$ \\
\hline \multirow[t]{2}{*}{ Using forceps for wearing CLs } & Yes & $3(10 \%)$ & $2(66.7 \%)$ & \multirow[t]{2}{*}{0.414} \\
\hline & No & $27(90 \%)$ & $23(85.2 \%)$ & \\
\hline \multirow[t]{3}{*}{ Rinsing lens with CL solution } & Always/ Often & $17(56.7 \%)$ & $14(82.4 \%)$ & \multirow{3}{*}{0.603} \\
\hline & Sometimes & $9(30 \%)$ & $7(77.8 \%)$ & \\
\hline & Rarely/ Never & $4(13.3 \%)$ & $4(100 \%)$ & \\
\hline \multirow[t]{3}{*}{ Rubbing lens with CL solution } & Always/ Often & $10(33.3 \%)$ & $8(80 \%)$ & \multirow{3}{*}{0.021} \\
\hline & Sometimes & $6(20 \%)$ & $3(50 \%)$ & \\
\hline & Rarely/ Never & $14(46.7 \%)$ & $14(100 \%)$ & \\
\hline \multirow[t]{3}{*}{ Using water for CLs storage } & Always/ Often & $4(13.8 \%)$ & $4(100 \%)$ & \multirow{3}{*}{0.316} \\
\hline & Sometimes & $4(13.8 \%)$ & $4(100 \%)$ & \\
\hline & Rarely/ Never & $21(72.4 \%)$ & $16(76.2 \%)$ & \\
\hline \multirow{3}{*}{$\begin{array}{l}\text { Frequency of addition solution } \\
\text { to CL storage cases }\end{array}$} & Daily & $17(56.7 \%)$ & $14(82.4 \%)$ & \multirow{3}{*}{0.494} \\
\hline & Weakly & $8(26.7 \%)$ & $6(75 \%)$ & \\
\hline & Monthly & $5(16.7 \%)$ & $5(100 \%)$ & \\
\hline \multirow{3}{*}{$\begin{array}{l}\text { Frequency of washing CL } \\
\text { storage cases }\end{array}$} & Always/ Often & $18(60 \%)$ & $16(88.9 \%)$ & \multirow{3}{*}{0.157} \\
\hline & Sometimes & $4(13.3 \%)$ & $4(100 \%)$ & \\
\hline & Rarely/ Never & $8(26.7 \%)$ & $5(62.5 \%)$ & \\
\hline \multirow[t]{4}{*}{ Washing CL storage cases by: } & Solution & $12(40 \%)$ & $10(83.3 \%)$ & \multirow{4}{*}{0.845} \\
\hline & Water & $11(36.7 \%)$ & $9(81.8 \%)$ & \\
\hline & Both & $3(10 \%)$ & $3(100 \%)$ & \\
\hline & Not washing & $4(13.3 \%)$ & $3(75 \%)$ & \\
\hline \multirow[t]{3}{*}{ CLs storage cases replacement } & Always/ Often & $15(50 \%)$ & $12(80 \%)$ & \multirow{3}{*}{0.852} \\
\hline & Sometimes & $6(20 \%)$ & $5(83.3 \%)$ & \\
\hline & Rarely/ Never & $9(30 \%)$ & $8(88.9 \%)$ & \\
\hline \multirow{3}{*}{$\begin{array}{l}\text { Addition of residual old } \\
\text { solution to the new one }\end{array}$} & Always/ Often & $4(13.3 \%)$ & $3(75 \%)$ & \multirow{3}{*}{0.494} \\
\hline & Sometimes & $1(3.3 \%)$ & $1(100 \%)$ & \\
\hline & Rarely/ Never & $25(83.3 \%)$ & $21(84 \%)$ & \\
\hline
\end{tabular}

Table (5) summarizes periods of using solutions and wearing lenses which was reported from the first date of commencement. Longer duration of CL care solutions usage is significantly associated with microbial contamination of CL units. More than one half (53.3\%) had their contact lenses for more than one year. Only (50\%) adhered to the manufacturer recommendations for proper use of CL care solution for less than 3 months. It should be noted that $45.5 \%$ of wearers use solutions for less than one month and use water when solution is not available. 
Table 5 Duration of using disinfectant care solutions and contact lenses

\begin{tabular}{|c|c|c|c|c|}
\hline CLs units & $\begin{array}{c}\text { Duration Periods } \\
\text { (Month) }\end{array}$ & $\begin{array}{l}\mathrm{N}=30 \\
\mathrm{n}(\%)\end{array}$ & $\begin{array}{c}\text { Microbial } \\
\text { Contamination } \\
\mathbf{n}=25(\%)\end{array}$ & $\begin{array}{c}P \text { - } \\
\text { value }\end{array}$ \\
\hline \multirow[t]{5}{*}{ CLs Solution } & $<1$ & $11(36.7 \%)$ & $10(90.9 \%)$ & \multirow{5}{*}{0.020} \\
\hline & $1-3$ & $4(13.3 \%)$ & $1(25 \%)$ & \\
\hline & $4-6$ & $2(6.7 \%)$ & $2(100 \%)$ & \\
\hline & $7-12$ & $4(13.3 \%)$ & $4(100 \%)$ & \\
\hline & $>12$ & $9(30.0 \%)$ & $8(88.9 \%)$ & \\
\hline \multirow[t]{5}{*}{ Contact lenses } & $<1$ & $3(10.0 \%)$ & $2(66.7 \%)$ & \multirow{5}{*}{0.105} \\
\hline & $1-3$ & $3(10.0 \%)$ & $3(100 \%)$ & \\
\hline & $4-6$ & 7 (23.3\%) & 7 (100\%) & \\
\hline & $7-12$ & $1(3.3 \%)$ & - & \\
\hline & $>12$ & $16(53.3 \%)$ & $13(81.3 \%)$ & \\
\hline
\end{tabular}

\section{Discussion}

Wearing CLs is a main risk factor that may lead to sight threatening aggressive events mainly microbial keratitis. Personal attitude, hygienic habits and practices toward lens handling are believed to be significant sources of contamination. The present study showed that $80 \%$ of participants, wearing CLs for periods ranging from 5 to 12 hours daily, have their CL units contaminated, particularly, those wearing CLs for periods exceeding 9 hours. This is in accordance with the study conducted among Indian college students where $70 \%$ of those reporting problems related to the use CLs (e.g., foreign body sensation, dry eyes, and watering eyes), wear CLs for 8 to 16 hours daily [32]. Eye redness and dryness are also reported after wearing contaminated CLs which is in accordance with the symptoms of a case presented by McVeigh et al. [18] of a woman aged 21 year old from Singapore which used to wear CLs most of the day, sometimes sleep with them and clean them with tap water over two months.

Although $60 \%$ of CL wearers have received instructions from health professional for safe handling of CLs, $88.9 \%$ of their CLs units were found contaminated. This could be due to the quality of information received by lens wearers or poor commitment to the instructions. Lievens, et al. [33] indicated that education and compliance of CL wearers with hygiene habits are some of challenges facing care providers, where experience of wearers is not necessarily sufficient for commitment and protection from risks. Bakkar and Alzghoul [34] concluded that level of commitment is high towards four habits including: personal use of CL, not sleeping while wearing, hand washing before wearing and not using water to clean lenses. Level of commitment was medium to low towards the following habits: bathing or swimming while wearing CLs, using CLs and solutions after the expiry date, and rinsing CL storage cases and aftercare visits. These are almost in agreement with the participants' awareness in the present study.

Microbial contamination was higher in CL units of wearers washing their hands with water or soap alternatively as compared to those using soap always. Barlow et al. [35] concluded that using antibacterial liquid soap greatly inhibits microbial contamination in CLs compared to ordinary soap or using water only or those not washing their hands before wearing CLs.

Using water or solution mixed with water to wash CL units by some participants is in accordance with Zimmerman et al. [36] study who reported that many CLs wearers use tap water to wash CLs and CL storage cases. Microbial contamination by varied types of bacteria may result when using tap water, since it may contain dangerous microorganisms such as Pseudomonas aeruginosa, Burkholderia cepacia, and Serratia. marcescens [37]. Besides, Shafqat, et al. [38] revealed the presence of Coliform group, Staphylococcus aureus and feacal Streptococcus in distribution systems of water. However, even distilled water if used to wash CL storage cases could be risky, because P. aeruginosa is able to grow relatively fast in distilled water, due to its very low nutritional requirement [39] and succeed tomaintain high level contaminations for long periods of time. On the other hand, Wu et al. [40] applied different modes to wash lens storage cases using CL solutions and distilled water as a control. It should be noted that CLs solution remains the 
most effective for cleaning, regardless of the washing method and type of solution, all solutions exert a significant effect in reducing biofilm formation compared to water $(\mathrm{P}=0.05)$.

According to instructions of use labeled on the bottles of CL solutions, the solution should not be used for more than three months after opening. Statistically significant association was reported between duration periods of using solutions and microbial contamination in CL units $(p=0.020)$. The overwhelming majority of wearers are using solutions for more than three months and their associated units were found contaminated (Table 5). Nevertheless, contamination was also reported in $90 \%$ of CL units of wearers using solutions for less than one month, which may be due to the fact that almost one half (45.5\%) of them use water when solution was not available. Dantam et al. [22] have reported a significant difference $(\mathrm{p}=0.013)$ between bacteria contaminating CL storage cases using different CL solutions types.

Incidence of contamination of CL storage cases is greatly affected by the manner of handling each item of CL units. When solutions in CL storage cases, adhere to the lenses, they easily get contamination and become a source of microbes that cause infection of the cornea and inflammatory reaction [23]. Improper hygienic practices and failure of some preservative systems are implicated in the development of the contamination. When lens wearers use bared fingers during immersion of lenses or removal from the disinfecting care solutions; skin commensals, transient pathogens and faecal bacteria may stuck in CL storage case and subsequently can be transferred to the disinfectants. Serratia and Pseudomonas species are known for their resistance to some disinfecting solutions [41, 42]. Despite presence disinfecting agent, CL storage cases may not be completely free of contaminants, because some factors may lead consistent bacterial survival such as formation of biofilm. Although all solutions exert a significant effect in reducing biofilm formation [43], but when it is formed in CL storage cases, will protect bacteria and prevent disinfectant solution to reach it [15]. The other factor including selectivity for contamination with cytotoxic strains as P. aeruginosa [44]. Eltis [45] and Mohammadinia et al. [46] reported that $90 \%$ of the causative agent of microbial keratitis is P. aeruginosa, followed by $S$. aureus. Both of which are multidrug resistant and responsible for nosocomial infections.

In the present study, more than one half CL wearers use their storage cases for more than one year, where microbial contamination was reported, which is largely inconsistent with the FDA [47] recommendations. However, Kim et al. [48] did not find microbial contamination in all expired or nearly expired CLs.

Rims of solution bottles are the first point that disinfectant solution pass through before reaching CLs, also it may touch immersion care solution in CL storage cases. This was confirmed by the recovery of the same type of M.O in the rim of bottles as well as its CL storage case which is in accordance with Nzeako and Al-Sumri [24].

\section{Strengths}

- The study design included structured questionnaire tackling different aspects on attitude, practice and hygienic habits connected to handling of each item of CL units.

- The unique aspect of this study, there is no available literature on swabbing rims of solution bottles which provided valuable information on this topic.

\section{Limitation}

- Small sample size because of curfew.

- Only female participants were available.

- Direct eye swab was not included.

\section{Conclusion}

Using water only to wash hands and CL storage cases has been incriminated for increased contamination. Thereby, impurities in CL storage cases have led to reduced efficacy of disinfectant care solutions. Value-added awareness of CL wearers should be improved by regular visit to eye care professionals.

\section{Compliance with ethical standards}

\section{Acknowledgments}

The authors are grateful to Dr. Abdullah Murhaf Al-Khani for his support and guiding through statistical analyses 


\section{Disclosure of conflict of interest}

The research is a part of MSc. Thesis of the first author, there is completely no conflict of interest and no fund was received from any source.If two or more authors have contributed in the manuscript, the conflict of interest statement must be inserted here.

\section{Statement of ethical approval}

The study was conducted according to the standards set by Helsinki Declaration of 1975, as reviewed in 2008." Approval to commence the study was obtained from the Ethical Committee of Isra University (No. Ph/03/19).

\section{Statement of informed consent}

Filling out the survey was contingent upon the participants' sign the informed consent form attached to the actual survey.

\section{References}

[1] Collier SA, Gronostaj MP, MacGurn AK, Cope JR, Awsumb KL, Yoder JS, Beach MJ. Estimated burden of keratitis-United States. 2010. Morbidity and Mortality Weekly Report. 2014; 63(45): 1027-1030.

[2] Cope JR, Collier SA, Nethercut H, Jones JM, Yates K, Yoder JS. Risk behaviors for contact lens-related eye infections among adults and adolescents - United States. 2016. Morbidity and Mortality Weekly Report. 2017; 66(32): 841845.

[3] Epstein AB. In the aftermath of the Fusarium keratitis outbreak: What have we learned? Clinical Ophthalmology. 2017; 1(4): 355-366.

[4] CDC. Healthy Contact Lens Wear and Care. 2020.

[5] Moreddu R, Vigolo D, Yetisen AK. Contact Lens Technology: From Fundamentals to Applications. Advanced Healthcare Materials. 2019; 8(15): e1900368.

[6] Weissman BA. Optometric Clinical Practice Guideline Care of The Contact Lens Patient. American Optometric Association: American Optometric Association. 2006.

[7] Suchecki JK, Donshik P, Ehlers WH. Contact lens complications. Ophthalmology Clinics of North America. 2013; 16(3): 471-484.

[8] Siddique M, Manzouri B, Flynn TH, Ono SJ. Allergy and contact lenses. Chemical Immunology and Allergy. 2007; 92: $166-175$.

[9] Arita R, Itoh K, Maeda S, Maeda K, Tomidokoro A, Amano S. Association of contact lens-related allergic conjunctivitis with changes in the morphology of meibomian glands. Japanese Journal of Ophthalmology. 2012; 56(1): 14-19.

[10] Upadhyay MP, Srinivasan M, Whitcher JP. Diagnosing and managing microbial keratitis. Community eye health. 2015; 28(89): 3-6.

[11] Khan SA, Lee CS. Recent Progress and Strategies to Develop Antimicrobial Contact Lenses and Lens Cases for Different Types of Microbial Keratitis. Acta Biomaterialia. 2020; 113(1): 101-118.

[12] Lemp MA. Contact lenses and associated anterior segment disorders: dry eye, blepharitis, and allergy. Ophthalmology Clinics of North America. 2003; 16(3): 463-469.

[13] Wiafe G Habtamu E, Onyango J, Gichuhi S, Leck A, Macleod D, Hu V, Matthew B. The impact of microbial keratitis on quality of life in Uganda. BMJ Open Ophthalmol. 2019; 4(1): e000351.

[14] Cope J, Konn N, Jacobs D, Dhaliwal D. Corneal Infections associated with sleeping in contact lenses - six cases, United States, 2016-2018. MMWR. Morbidity and mortality weekly report. 2018; 67(32): 877-881.

[15] McLaughlin-Borlace L, Stapleton F, Matheson M, Dart JK. Bacterial biofilm on contact lenses and lens storage cases in wearers with microbial keratitis. Journal of Applied Microbiology. 1998; 84(5): 827-838. 
[16] Lim C, Stapleton F, Mehta J. Review of Contact Lens-related complications. Eye Contact Lens Science and Clinical Practice. 2018; 44: S1-S10.

[17] Fleiszig SM, Evans DJ. Pathogenesis of contact lens-associated microbial keratitis. Optometry and Vision Sience. 2010; 87(4): 225-232.

[18] McVeigh K, Vahdani K, Tavassoli S, Tole D. Painful red eyes in a contact lens wearer. General Medical Journal. 2017; 358: j3614.

[19] Devonshire P, Munro FA, Abernethy C, Clark BJ. Microbial contamination of contact lens cases in the west of Scotland. British Journal of Ophthalmology. 1993; 77(1): 41-45.

[20] Wu YT, Zhu H, Willcox M, Stapleton F. Removal of biofilm from contact lens storage cases. Investigative Ophthalmology \& Visual Science. 2010; 51(12): 6329-6333.

[21] Yung MS, Boost M, Cho P, Yap M. Microbial contamination of contact lenses and lens care accessories of soft contact lens wearers (university students) in Hong Kong. Ophthalmic and Physiological Optics. 2007; 27(1): 1121.

[22] Dantam J, McCanna DJ, Subbaraman LN, Papinski D, Lakkis C, Mirza A, Jones LW. Microbial Contamination of Contact Lens Storage Cases During Daily Wear Use. Optometry and Vision Science. 2017; 93(8): 925-932.

[23] Szczotka-Flynn L, Lass JH, Sethi A, Debanne S, Benetz BA, Albright M, Rimm A. Risk factors for corneal infiltrative events during continuous wear of silicone hydrogel contact lenses. Investigative Ophthalmology \& Visual Science. 2010; 51(11): 5421-5430.

[24] Nzeako BC, Al-Sumri SH. The Disinfecting Potential of Contact Lens Soutions used by Sultan Qaboos University Students. Sultan Qaboos University Medical Journal. 2011; 11(2): 252-258.

[25] Dantam J, McCanna, DJ, Subbaraman LN, Lakkis C, Morgan PB, Nichols JJ, Jones LW. Microbial contamination of contact lens storage cases with the use of different contact lens care solutions and lens materials. Investigative Ophthalmology \& Visual Science. 2014; 55(13): 4675-4675.

[26] Mohamed JA, Abdallah SM, Alatrouny AM. Bacterial Interactions among Soft Contact Lens Users and Lens Care Solutions with Antibiotic Susceptibility Pattern. The Egyptian Journal of Hospital Medicine. 2017; 68(1): 982990.

[27] Bhandari M, Hung PR. Habits of contact lens wearers toward lens care in Malaysia. Medical Journal of Malaysia. 2012; 67(3): 274-277.

[28] Stapleton F, Naduvilath T, Keay L, Radford C, Dart J, Edwards K, Holden B. Risk factors and causative organisms in microbial keratitis in daily disposable contact lens wear. PLoS One. 2017; 12(8): e0181343.

[29] American Academy of Optemetry AOA. Healthy Vision and Contact Lenses.

[30] Kelsey JC. An improved Kelsey-Sykes test for disinfectants. The Journal of Applied Bacteriology. 1974; 213: 528530.

[31] Denyer SP, Hodges NA, Gorman SP. Hugo and Russell's pharmaceutical microbiology: John Wiley \& Sons. 2008.

[32] Unnikrishnan B, Hussain S. Pattern of use of contact lens among college students: a cross-sectional study in coastal Karnataka. Indian Journal Ophthalmol. 2009; 57(6): 467-469.

[33] Lievens CW, Cilimberg KC, Moore A. Contact lens care tips for patients: an optometrist's perspective. Clinical Optometry. 2017; 9: 113-121.

[34] Bakkar MM, Alzghoul EA. Assessment of compliance with contact lens wear and care among university-based population in Jordan. Contact Lens and Anterior Eye. 2020; 43(4): 395-401.

[35] Barlow M, Plank D, Stroud S, Henry VA, Tumosa N, Bennett ES. The effectiveness of typical hand-cleaning methods on hydrogel contact lenses. International Contact Lens Clinic. 1994; 21(11-12) : 232-236.

[36] Zimmerman AB, Richdale K, Mitchell GL, Kinoshita BT, Lam DY, Wagner H, Yoder JS. Water Exposure is a Common Risk Behavior Among Soft and Gas-Permeable Contact Lens Wearers. Cornea. 2017; 36(8): 995-1001.

[37] Minogue E, Tuite NL, Smith CJ, Reddington K, Barry T.A rapid culture independent methodology to quantitatively detect and identify common human bacterial pathogens associated with contaminated high purity water. BMC Biotechnology. 2015; 15(1): 6. 
[38] Shafqat M, Batool A, Kazmi S, Imad S, Ghufran M, Samad N. Drinking water quality, water distribution systems and human health: a microbial evaluation of drinking water sources in salt range. International Journal of Hydrology. 2018; 2(5): 542-547.

[39] Favero MS, LA Carson, WW Bond, NJ Petersen. Pseudomonas aeruginosa: growth in distilled water from hospitals. 1971:; 173(3999): 836-8.

[40] Wu YT, Zhu H, Willcox M, Stapleton F. The effectiveness of various cleaning regimens and current guidelines in contact lens case biofilm removal. Investigative Ophthalmology \& Visual Science. 2011; 52(8): 5287-5292.

[41] Mayo MS, Schlitzer RL, Ward MA, Wilson LA, Ahearn DG. Association of Pseudomonas and Serratia corneal ulcers with use of contaminated solutions. Journal of Clinical Microbiology. 1987; 25(8): 1398-1400.

[42] Willcox MD. Review of resistance of ocular isolates of Pseudomonas aeruginosa and staphylococci from keratitis to ciprofloxacin, gentamicin and cephalosporins. Clinical and Experimental Optometry. 2011; 94(2): 161-168.

[43] Artini A, Cellini A, Scoarughi GC, Papa R, et al. Evaluation of Contact Lens Multipurpose Solutions on Bacterial Biofilm Development. Eye \& contact lens. 2015; 41(3): 177-182.

[44] Lakkis C, Fleiszig SMJ. Resistance of Pseudomonas aeruginosaisolates to Hydrogel Contact Lens Disinfection Correlates with Cytotoxic Activity. Journal of Clinical Microbiology. 2001; 39(4): 1477-1486.

[45] Eltis M. Contact-lens-related microbial keratitis: case report and review. Journal of Optometry. 2011; 4(4): 122127.

[46] Mohammadinia M, Rahmani S, Eslami G, Ghassemi-Broumand M, Amiri MA, Aghaie G, Behgozin AJ. Contact lens disinfecting solutions antibacterial efficacy: Comparison between clinical isolates and the standard ISO ATCC strains of Pseudomonas aeruginosa and Staphylococcus aureus. Eye (Lond). 2012; 26(2): 327-330.

[47] FDA. Focusing on Contact Lens Safety. 2019.

[48] Kim SR, Kim DJ, Hwang HW, Park MJ. The stability and safety evaluations of soft contact lenses past their expiry date. The Korean Ophthalmic Optics Society. 2017; 22(1): 33-40. 